\title{
THE MAIN DIRECTIONS OF PENSION SYSTEMS DEVELOPMENT IN THE WORLD AND IN UZBEKISTAN
}

\author{
Makhmudjon Djurakulovich Ziyadullaev \\ Deputy Chairman of the State Committee of the Republic of Uzbekistan on Statistics, \\ $\mathrm{PhD}$ in Law
}

Article DOI: https://doi.org/10.36713/epra1494

\begin{abstract}
This article highlights the world experience of the pension system and social protection of citizens, social policy in the transition period to a market economy, in addition, having pension systems and the main directions for their development, the main demographic factors affecting the pension system. It also describes the reforms carried out in recent years in the Republic of Uzbekistan, benefits provided to pensioners, and current problems of the pension system, as well as substantiated proposals for improving pension legislation.
\end{abstract}

KEY WORDS: old-age pension, pension system, pension, social protection, benefits, social assistance, pension fund.

\section{INTRODUCTION}

The strong social protection policy pursued in the Republic of Uzbekistan requires ensuring reliable legal aspects in all respects. This requires further improvement of social protection systems, including pension systems, the adoption of the necessary legislative acts and documents in this area. As the President of the Republic of Uzbekistan Sh. Mirziyoyev noted, "Support for disabled people, those who have lost their breadwinners, lonely elderly people, in general, those who need support, of course, remains a priority task of the Republic of Uzbekistan. In the future, a lot of work has to be done to create more favorable conditions for entrepreneurship, doing business, creating new jobs, increasing incomes of the population, improving pension provision "[1].

\section{METHODS}

All this requires the creation of a legal concept for the effective implementation of reforms in the pension system of Uzbekistan, the definition of its main directions. The adoption of the Law of the Republic of Uzbekistan "On state pension provision of citizens" was of great importance in the formation of the pension system in Uzbekistan. The purpose of the law is to ensure the position of pensioners in society, their legal protection in a market economy, determine the size of the pension, which directly depends on the length of service and the amount of wages.

The transition to a market economy has both positive and negative aspects, including the fact that the stratification of the country's population by income level leads to social instability. To mitigate these social problems, each country has its own social policy. The essence of such a policy is that the state clearly develops and tries to cover those strata of the population that, for some reason, are not able to earn a living. The existence of an effective social security system in the country will help overcome those social problems that may arise.

\section{RESULTS AND DISCUSSIONS}

It is known that in the Republic of Uzbekistan, pension payments are mainly based on the principle of "solidarity of generations", that is, pensions are paid out of the contributions of those who work. Therefore, there must be a certain balance between the number of pensioners and the number of working citizens. If there is a change in the demographic situation in Uzbekistan, as well as an increase in the number of self-employed and 
unemployed in the informal sector, then this balance may be upset in the future.

The implementation of a strong social policy in Uzbekistan at the stage of economic liberalization and in the context of deepening reforms requires the use of new practical and effective forms. World experience shows that the creation and effective use of the system of state trust funds plays an important role.

The development of a market economy designed to meet the needs of every member of society is at the heart of government fiscal policy. Because the social interests of each person or any social group, as well as the nation, are always reflected in the relations of the social system and the expenditures of the state budget, which meet its social needs. At the stage of economic liberalization, the implementation of an active social policy in countries requires the use of new practical and effective forms.

Now one of the most important social problems of states is to improve the living standards of the population. And one of the main ways to solve this problem will be pension provision, which will allow pensioners to live well. The purpose of creating a pension system is not to make the state charitable, to protect older citizens from poverty, but to come up with a way to finance the pension system that will allow a person to live fully when he is old, to ensure social justice.

According to the UN conclusions, in pension systems based on "solidarity of generations" - if there are four employees per pensioner, then this pension fund is considered stable. To ensure the stability of social policy, the country determines the main directions for improving reforms. In different states, the ways to achieve this goal differ from each other. The study of changes in the age structure of the world's population showed that the retirement age is more burdensome for the working-age population, which can be explained by objective demographic changes, and this can be observed in many countries and regions. Currently in developed countries there is a significant increase in the proportion of the adult population to the middle-aged population.

In almost all countries, after the second half of the last century, life expectancy has increased by an average of 20 years, while in the 21 st century it is expected to increase by another 10 years by 2050 . In European countries alone, the average age of the population in 1995 was 36 , today it is [2] 42, and by 2050 it is 57 . For reference, the average age of the population in our republic at the moment is 29 years.

The issue of pension provision, especially in the 80 s of the XX century, was difficult, since it was at this time that the reforms of the pension system were launched in developed and developing countries of the world. As the gap between working citizens (those who pay) and those who do not work (those who receive a pension) increased, many problems arose in the distribution system, and this problem forced the reform of the pension system. The difference in pension coverage was mainly covered by government spending, which led to changes in the pension system.

The study of world experience in the field of pension provision shows that the pension system in different countries is different and it depends on the economic level of the state, its size, habits, experience of social security, employee discipline and pension security.

For example, the main directions of the pension reform in the Czech Republic are the abolition of benefits for unhealthy work, the introduction of additional contributions to the insurance premiums of employers, the establishment of a link between the contributions paid and the received pensions, the development of a diversified insurance system, the expansion of the possibilities of individual pension plans, an increase in the retirement age for men and women.

Currently, more than 200 models of methods of payment of funded and distributed pensions are used in the world. At the end of the last century, Chile, Bolivia, El Salvador, Mexico and Kazakhstan abandoned this method of distribution and switched only to the method of accumulating pensions [3].

The method of accumulating pensions is more stable and does not affect demographic changes, the method of distribution is more suitable for economic and demographic needs, but these characteristics do not fully achieve the main goal of pension policy. As a result of combining these methods, the distribution method is used - collection, in which, at the expense of the working population, the society pays a pension to those who do not work, and an additional pension is issued from the income received from investing in financial markets.

Most developed countries currently use a three-tier pension system:

Stage 1 - compulsory state support, distributed over certain age groups;

Stage 2 is a compulsory accumulation method, in which the amount of the pension is collected in the individual accounts of the pensioner and depends on the amount to be invested;

Stage 3 - voluntary pension insurance.

In the current demographic situation, we believe that the main tasks of the pension system should be the following:

a) lack of opinion that the pensioner's income is sufficient, that is, a person's life will deteriorate as a result of retirement;

b) people of retirement age must be protected from social, economic hardships, human and physical aspects must be taken into account. 
In conclusion, I would like to note that it is necessary to strengthen the ongoing work to increase the stability of the pension system, in particular, the income base of the population.

Today, a reliable pension system has been formed in Uzbekistan, which has a solid legal basis in all respects.

Especially over the past 3-4 years, largescale reforms have been carried out to increase the size of pensions and further improve the social protection system. According to the Decree of the President of the Republic of Uzbekistan "On the State Program for the Implementation of the Strategy of Action in Five Priority Areas of Development of the Republic of Uzbekistan in 2017-2021 in the Year of Supporting Youth and Strengthening the Health of the Population" in order to create the most favorable conditions for citizens when assigning pensions and benefits, it is established the procedure according to which from June 1, 2021:

- when assigning a pension, seniority for the period up to 2005, when an electronic database on wages and seniority was not maintained, is calculated on the basis of the records of the person's seniority in the work book without requesting supporting documents;

- the verification and collection of excessive payments on assigned, recalculated pensions and benefits for a period of three or more years is canceled;

- working citizens are given the right to make, on a voluntary basis, a monthly payment of social tax from their own income in order to receive future retirement benefits for their non-working spouses;

- pensions and benefits are assigned and paid at the request of the citizen at the place of permanent registration or place of temporary stay;

- applications for pensions and benefits in non-cash form are drawn up by citizens in the process of opening bank plastic cards in branches of commercial banks or in electronic form through mobile applications without contacting the appropriate branch of the off-budget Pension Fund under the Ministry of Finance;

- the obligation of persons receiving pensions in a non-cash form to visit the Pension Fund every six months, as well as responsible employees, is canceled - to conduct on-site monitoring to determine whether citizens have lost their right to a pension on the basis of electronic information provided by the relevant ministries and departments.

Despite all this, we must also recognize that there are issues that have not yet been resolved, there are many problems that need to be addressed. In this regard, it is necessary, first of all, further improvement of the regulatory and legal framework for pension provision, a clear definition of norms in accordance with modern requirements, a revision of the existing legal framework and the introduction of appropriate additions and changes to the existing regulatory and legal documents, it is necessary to put on the agenda of increasing the efficiency of pension provision.

The legal framework that will be developed and adopted in the country should take into account the new, changing socio-economic and demographic conditions of the republic, create convenience for providing additional social protection in old age, the formation of pension funds, and it is necessary to clearly define the directions of spending funds, take into account the gradual equalization, or although would be the approximation of the conditions for determining pensions for men and women, the abolition, or a significant reduction in preferential pensions.

Taking into account the above, along with the ongoing social reforms and based on the experience of developed countries, it is desirable to create additional corporate, collective, private funds and off-budget social funds aimed at the national pension system, as well as introduce preferential pensions through corporate, collective private pension funds.

\section{CONCLUSION}

Based on the above proposals, it is necessary to start a phased introduction of corporate and private pension systems while maintaining the state pension system. Currently, the creation of their legal base is an urgent task. Non-state pension funds play an important role and significance in advancing the pension system of Uzbekistan to a new level.

It is also possible to develop measures to attract entrepreneurs to the system of accumulative pension funds, which will allow them to receive income for additional pensions in the future. In this regard, it is necessary to study in more detail the reforms of the pension system in foreign countries and apply the relevant aspects of cost control in Uzbekistan.

In the future, deepening and increasing the effectiveness of socio-economic reforms will lead to a constant increase in the quantity and quality of social assistance provided to citizens of the Republic of Uzbekistan and society, while pension coverage will begin to receive wide coverage not only at the expense of public funds, but also at the expense of the resources of members of society.

\section{REFERENCES}

1. Message from the President of the Republic of Uzbekistan Sh. Mirziyoyev to the Oliy Majlis. "Khalk suzi", December 29, 2018 271-272 (7229-7230)

2. Data from the United Nations Population Fund.

3. 3.www.OECD.org (@) 2018 Organization for Economic Co-operation and Development) 
4. Law of the Republic of Uzbekistan dated December 2, 2004 "On accumulative pension provision of citizens". Collection of documents of the Law of the Republic of Uzbekistan. 2001, No. 51 , article 512.

5. Law of the Republic of Uzbekistan "On funded pensions" and its implementation in 2005. - T.: Uzbekistan, 2006.

6. Tax Code of the Republic of Uzbekistan. National database of legislation of the Republic of Uzbekistan.

7. 7.Resolution of the Cabinet of Ministers of the Republic of Uzbekistan dated May 12, 1994 No. 250 "On approval of the list of industries, institutions, jobs, professions, positions and indicators that give the right to retire on preferential terms". National database of legislation of the Republic of Uzbekistan.

8. 8. Mirziyoyev Sh.M. An educated generation is a guarantee of a great future, an enterprising nation is a prosperous life, and friendly cooperation is a guarantee of progress. www.xs.uz official website and "Khalk suzi", December 8, 2018. 253 (7211).

9. 9. Inoyatov A.A. other. Social Security Act. - T: TSJI. 2002. 